\title{
Utilisation of common leafy vegetables in the diets of giant West African snail Archachatina marginata (Swainson, 1821) (Stylommatophora: Achatinidae)
}

\section{Maduabuchi Inwele Amobi ${ }^{1}$ and Bede Izuchukwu Ezewudo ${ }^{2}$}

\author{
${ }^{1}$ Department of Biological Sciences. Federal University. Kashere. Gombe State. \\ Nigeria. \\ ${ }^{2}$ Department of Zoology and Environmental Biology. University of Nigeria. Nsukka. \\ Nigeria. Email: ezewudobede@gmail.com.
}

\begin{abstract}
A study was conducted to evaluate the effects of utilisation of three leafy vegetable diets (bitter leaf Vernonia amygdalina, fluted pumpkin leaf Telfairia occidentalis and pawpaw leaf Carica papaya) on the growth performance of giant West African snail Archachatina marginata. A total of 90 A. marginata were used for the study. 30 snails were also subjected to three different dietary treatments in three replicates of 10 snails per replicate and fed with the fresh leaves of these vegetables over a period of 12 weeks. Results obtained recorded significant differences $(\mathrm{P}<0.05)$ in terms of weight gain, shell length, shell circumference and shell thickness. On the whole, Archachatina marginata fed on fluted pumpkin leaf performed better in terms of mean weight gain when compared with those fed on bitter and pawpaw leaves. On the other hand, snails fed on pawpaw leaf had the best mean shell length gain, mean shell circumference and mean shell thickness when compared with those fed on bitter and fluted pumpkin leaves. The result clearly showed that the tested leafy vegetables can be successfully utilised as diets for rearing of $A$. marginata. For farmers to achieve better result, the inclusion of fluted pumpkin and pawpaw leaves in the diets of Archachatina marginata is highly recommended in snail rearing businesses.
\end{abstract}

Keywords: Archachatina marginata; Bitter leaf; Fluted pumpkin; Growth performance; Pawpaw.

\section{Introduction}

Low amount of animal proteins in the daily diets of Nigerians has been linked to the increased protein-related deficiency diseases in the country (FAO, 1986; Kehinde et al., 2002). The current state of the Nigerian economy has not
Received

January 31, 2019

Accepted

April 19, 2019

Released

April 30, 2019

Full Text Article

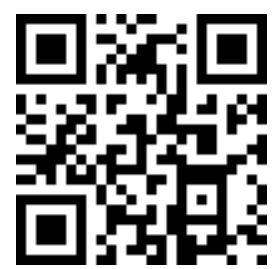

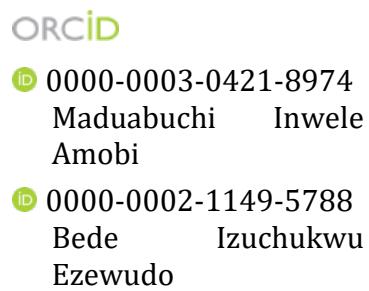


favourably in providing the needed nutrients found in the conventional animal proteins has gained a lot of attention in the research world of animal scientists. One of the animals that have garnered enormous research recently is snail.

Snail rearing, also known as heliculture, is seen as the avenue of bridging the protein deficiency bedeviling the country. This is because snail meat is found to be rich in protein, low in lipid and contains essential minerals like zinc, iron, calcium and magnesium (Orisawuyi, 1989; Ademolu et al., 2004). Also, the shells are of economic importance as they can serve as a source of calcium and phosphorous in formulating animal diets and for ornamental uses (Baba and Adeleke, 2006; Houndonougbo et al., 2012). Snail farming businesses have witnessed an astronomical growth in the country due to high costs of conventional animal proteins, the availability of the edible snails such as Limicolaria species, Archachatina marginata, Achatina achatina, Achatina fulia; high market demand both locally and internationally and improved technologies for their mass production (Amusan and Omidiji, 1998).

The Giant West African snail is endemic to West Africa but can be found in other continents (Raut and Barker, 2002). Unlike Achatina fulica and Achatina achatina that can lay up to 200500 eggs per clutch (Raut and Barker 2002); A. marginata has a lower egg production rate and can lay up to 4-18 eggs per clutch (Omole and Kehinde, 2005). Like other snails, $A$. marginata has voracious appetite and feeds on a wide range of crops, inflicting various degrees of damage to food crops and vegetables (Mead, 1979; Raut and Barker, 2002) at ferocious rate. It also serves as intermediate host of the rat lungworm parasites (Angiostrongylus cantonensis and $A$. costaricensis) that cause a human disease known as eosinophilic meningitis (Marquard et al., 2000, CDC, 2018).
The inclusion of Archachatina marginata in snail rearing businesses in Nigeria is linked to its massive size, good taste, high feeding plasticity of a wide range of available plant materials and detritus and utilisation in traditional healthcare (Olufokunbi et al., 1989; Agbelusi and Ejidike, 1992; Raut and Barker, 2002). Surprisingly, the potentials of snail domestication and its mass production in Nigeria have not been fully exploited (Agbogidi and Okonta, 2011) due to seasonal availability of snails and the scarcity of snail feeds that are nutritionally balanced and less cheap. It is found that giant West African snails are more active and productive during the rainy season but aestivate and remain dormant during the dry season, leading to its scarcity (Ejidike and Omisade, 2007). Also, for a successful snail rearing business in Nigeria, there is need for availability of cheap and nutritionally balanced diets throughout the season.

However, given that information on the exact feed of plant origin that can boost snail farming businesses for commercial purposes has received little attention, the current study attempted to bridge the gap in knowledge on suitable common leafy vegetables and their nutritive properties that can be incorporated in the diets of snails for maximum result under intensive system.

\section{Materials and methods}

\section{Study site}

The study was conducted in a commercial snail farm located in Iyi-Enu, Ogidi town, in Idemili North Local Government Area, Anambra State, Nigeria. Ogidi lies in the tropical region experiencing an annual rainfall of $1,000 \mathrm{~mm}-1,500 \mathrm{~mm}$ with two seasons the dry and rainy season, and average annual temperature of $26.6^{\circ} \mathrm{C}$ (Okafor, 2011).

The farm had a total land area of $100 \mathrm{~m}^{2}(10 \mathrm{~m} \times 10 \mathrm{~m})$. Each snail pen was housed in a roofed enclosure 
protected from direct rain and sunlight. The construction of the enclosure adopted the methods described by Cobbinah et al. (2008). Each enclosure was padded with aluminum roofing sheets and ceiling boards. Also, trees were planted in the farm to provide further shade and wind actions.

\section{Experimental procedure, leafy vegetables and snails}

Archachatina marginata were purchased from the Ministry of Agriculture Awka, Anambra State, Nigeria, and transported to the farm in local baskets covered with banana leaves. Three different leafy vegetables [bitter leaf (Vernonia amygdalina), fluted pumpkin leaf (Telfairia occidentalis) and pawpaw leaf (Carica papaya)] were sourced fresh, served as diets for the snails and analysed for their proximate composition according to AOAC (2005) methodologies.

90 A. marginata individuals were used for the study. Prior to the feeding trial, the snails were acclimatised for two weeks, fed with maize chaff and water supplied in a closed system. 30 A. marginata specimen were subjected to each of the three experimental diets in three replicates of 10 snails per replicate. By adopting the stocking density as explained by Cobbinah et al. (2008), each group of snails was placed in a mini paddock pen measuring $120 \mathrm{~cm} \times 60 \mathrm{~cm}$ $\times 30 \mathrm{~cm}$. The bedding was prepared with humus soil to a depth of $20 \mathrm{~cm}$, sprinkled daily to keep it moist and avoid estivation of snails as a result of dryness and high temperature increase. In order to improve the dietary calcium requirement of the snails, each treatment received $50 \mathrm{~g}$ of ground egg shell which was applied in the bedding.

\section{Data collection and statistical analysis}

The growth performance of Archachatina marginata was determined by measuring the following parameters body weight was taken with the aid of a sensitive weighing balance, shell length and circumference were measured using a veneer caliper. Shell thickness was ascertained using a micrometer screw gauge. The results obtained were subjected to analysis of variance (ANOVA) (SAS, 2001). Significant differences between means were separated using a post hoc test (Least Significant Difference) (SAS, 2001).

\section{Results}

\section{Proximate composition of tested vegetable diets}

Table 1 reveals the results of the proximate analysis of the tested vegetable diets. The results show higher dry matter and crude protein contents with lower crude fat and calcium concentrations in all the three tested vegetable diets. Highest dry matter was observed in bitter leaf while highest protein content was recorded in fluted pumpkin leaf. Pawpaw leaf had appreciable amounts of crude fibre, ash, crude fat and phosphorus compared to the other two experimental diets.

Table 1. Proximate composition of experimental leafy diets (\%)

\begin{tabular}{lccc}
\hline Parameters & Bitter leaf & Fluted pumpkin leaf & Pawpaw leaf \\
\hline Dry matter & 23.40 & 19.75 & 21.84 \\
Crude protein & 20.94 & 23.08 & 22.53 \\
Crude fibre & 12.26 & 6.39 & 13.98 \\
Ash & 9.38 & 8.94 & 9.76 \\
Crude fat & 0.08 & 0.12 & 1.24 \\
Calcium & 0.18 & 0.19 & 0.16 \\
Phosphorus & 1.15 & 1.20 & 1.21 \\
\hline
\end{tabular}




\section{Growth performance}

Table 2 reveals that in all treatments there was a progressive increase in all growth parameters studied over time, recording significant statistical differences. There was statistical difference $(\mathrm{P}<0.05)$ in the mean weight gain of Archachatina marginata subjected to each feeding treatment throughout the feeding trial. The results also show that $A$. marginata fed with fluted pumpkin leaf had the highest mean weight gain while the least gain was recorded for snails fed with bitter leaf. Also, significant differences were observed for mean shell length increase but snails fed with pawpaw leaf had the best mean shell length compared to the snails fed on the other leaves. The tested vegetable diets showed significant differences $\quad(P<0.05) \quad$ in shell circumference and in shell thickness with remarkable increases.

Table 2. Growth performance of snails before and after the feeding trial.

\begin{tabular}{lcccc}
\hline Growth parameters & Bitter leaf & $\begin{array}{c}\text { Fluted } \\
\text { pumpkin } \\
\text { leaf }\end{array}$ & $\begin{array}{c}\text { Pawpaw } \\
\text { leaf }\end{array}$ & SEM \\
\hline Initial mean weight (g) & 37.80 & 39.20 & 38.90 & 0.900 \\
Final mean weight (g) & 92.70 & 123.20 & 116.30 & 3.950 \\
Mean weight gain (g) & 54.90 & 84.10 & 77.40 & 12.000 \\
\hline Initial shell length (cm) & 4.51 & 4.50 & 4.60 & 0.095 \\
Final shell length (cm) & 7.52 & 7.60 & 7.84 & 0.200 \\
Mean shell length gain (cm) & 3.01 & 3.10 & 3.24 & 0.180 \\
Initial shell circumference (cm) & 7.60 & 7.26 & 7.66 & 0.200 \\
\hline Final shell circumference (cm) & 14.68 & 14.29 & 15.00 & 0.310 \\
Mean shell circumference gain (cm) & 7.05 & 7.04 & 7.34 & 0.265 \\
\hline Initial shell thickness (mm) & 24.47 & 25.09 & 24.24 & 0.930 \\
Final shell thickness (mm) & 30.13 & 30.70 & 30.61 & 0.545 \\
Mean shell thickness gain (mm) & 5.66 & 5.61 & 6.37 & 0.740 \\
\hline
\end{tabular}

* SEM $=$ Standard error of mean.

\section{Discussion}

\section{Proximate composition of tested vegetable diets}

The study revealed that these tested vegetables contain appreciable amount of protein. This suggests that these vegetables could successfully serve as good dietary sources of protein. The crude protein contents of the experimental diets of 20.94\%-23.08\% slightly conform to other reports on the crude protein contents of these three tested vegetables. The protein content of bitter leaf in this study compares well to the $20.1 \%$ reported by Opega et al. (2016). In fluted pumpkin leaf, the protein content recorded in this study slightly agrees to the $25.49 \%$ reported by Abu et al. (2014), whereas the present crude protein content of pawpaw does not tally with the finding $(33.4 \%)$ of Maisarah et al. (2014). The variations in proximate composition could be a result of handling processes deployed during the proximate analyses. It could also relate to the fertility nature of the soils on which the plants were grown, since nutrient-rich soils beget plants with nutrient-rich leaves.

The high ash content of the three leafy vegetables shows that they contained required amount of minerals (Antia et al., 2006) needed by the snails. 
The presence of moderate concentrations of crude fibre in all diets shows that the diets would be easily assimilated in the digestive system of the snails. This is because presence of appreciable dietary fibre helps to improve bowel movement and assimilation of nutrients (Sizer and Whitney, 2003; Lunn and Buttriss, 2007).

\section{Growth performance}

In Archachatina marginata, the varying effects of bitter, fluted pumpkin and pawpaw leaves on its growth performance recorded in this study conform to the results generated by Okonta and Agbogidi (2011). These authors observed significant increases in mean weight gains when three vegetable feeds (Amaranmthus cruetus, Carica papaya and Talinum triangulare) where administered on two different species of snails; Achatina achatina and Archachatina marginata. On the contrary, the results of Mogbo et al. (2014) disagree with our results as they observed that Achatina fulica, a family member (Achatinidae) of Archachatina marginata fed with three different leaves, Moringa oleifera, Carica papaya and Talinum triangulare recorded no significant difference in the mean weight gain of the snail. That snails fed with fluted pumpkin leaf yielded the best result in terms of weight gain could relate to the high crude protein content of these leaves (Essien et al., 1992), since protein promotes tissue growth and development. In addition, it was found that fluted pumpkin leaf was slightly more succulent, and probably more palatable and digestible than the other two leaves, hence this could be the reason why snails fed with fluted pumpkin recorded the best weight gain.

Also, significant differences were observed in both the mean shell length and shell circumference of snails fed on the three different leafy vegetables. Our findings are in line with the observations of Okonta and Agbogidi (2011). These authors observed significant differences in both the mean shell length and circumference of Archachatina marginata fed with three different vegetable diets. The results also indicated that snails fed with pawpaw leaf recorded the best mean shell length and circumference. These suggest that pawpaw leaf may contain essential minerals like calcium, phosphorous, potassium, needed for the growth of the snails. The finding of Ayoola and Adeyeye (2010) also validate our results as they discovered high amount of calcium $(8,612.50 \mathrm{mg} / \mathrm{kg})$ and potassium $(2,889$ $\mathrm{mg} / \mathrm{kg}$ ) in pawpaw leaf.

Progressive increase in mean shell thickness was observed in all the snails exposed to the different experimental diets. The extra addition of ground egg shell as calcium supplement in the bedding might be the reason for the noticeable increase in shell thickness of the snails. Though, it was found that snails fed with pawpaw leaf recorded the best mean shell thickness. This could be related to appreciable phosphorous content $(1.21 \%)$ and other minerals in pawpaw leaf compared to the other two leaves. It was found that high concentration of minerals such as calcium, iron and phosphorous in the shell of Achatina achatina improves its shell thickness (Ademolu et al., 2016).

\section{Conclusion}

This study has revealed that the utilisation of leafy vegetables (bitter leaf, fluted pumpkin leaf, pawpaw leaf) in the dietary menus of $A$. marginata has varying effects on growth performance of A. marginata. Furthermore, this study also showed that snails fed with fluted pumpkin and pawpaw leaves recorded better growth performance than with bitter leaf. Therefore, inclusion of fluted pumpkin and pawpaw leaves in the diets of Archachatina marginata is highly recommended for optimum productivity in snail rearing businesses. 


\section{Acknowledgements}

The authors wish to acknowledge in a special way the inputs of Mr. Afocha of the Ministry of Agriculture, Awka, Anambra State, Nigeria, for assisting in acquiring and identifying the species of snail used for the study. Also, the role of Dr. T. C. Mogbo of the Department of Zoology, Nnamdi Azikiwe University, Awka, Anambra State, Nigeria, in recommending the best pen houses that were used for the study is highly appreciated.

\section{Conflicts of interest}

Authors declare that they have no conflict of interests.

\section{References}

Abu, N. E.; Ozoagudike, C. M.; Akaneme, F. I. Phytochemical, proximate and anti-nutrient compositions of four leafy vegetables used in south eastern Nigeria. African Journal of Biotechnology, v. 13 , no. 50, p. 4541-4546, 2014.

Ademolu, K. O.; Idowu, A. B.; Mafiana, C. F.; Osinowo, O. A. Performance, proximate and mineral analyses of African giant land snail (Archachatina marginata) fed different nitrogen sources. African Journal of Biotechnology, v. 3, no. 8, p. 412-417, 2004.

Ademolu, K.; Olaniyi, P.; Ebenso, I.; Idowu, B. Morphometrics and mineral composition of shell whorls in three species of giant African snails from Abeokuta, Nigeria. Folia Malacologica, v. 24, no. 2, p. 81-84, 2016. https://doi.org/10.12657/folmal.024.013

Agbelusi, E. A.; Ejidike, B. N. Utilizatioin of the African giants land snail Archachatina marginata in the humid area of Nigeria. Tropical Agriculture, v. 69, no. 1, p. 88-92, 1992.

Agbogidi, O. M.; Okonta, B. C. Reducing poverty through snail farming in Nigeria. Agriculture and Biology Journal of North America, v. 2, no. 1, p. 169-172, 2011. https://doi.org/10.5251/abjna.2011.2.1.169. 172
Akegbejo, S.; Akinnusi, O. Effects of population density on the growth and egg laying capacity of African giant snail $A$. marginata. Nigerian Journal of Animal Production, v. 27, p. 99-103, 2000.

Amusan, J. A.; Omidiji, M. O. Edible land snails: A technical guide to snail farming in the tropic. Ibadan: Verify Printers, 1998. p. 19-22.

Antia, B. S.; Akpan, E. J.; Okon, P. A.; Umoren, I. U. Nutritive and anti-nutritive evaluation of sweet potatoes (Ipomoea batatas) leaves. Pakistan Journal of Nutrition, v. 5, p. 166-168, 2006.

AOAC - Association of official Analytical Chemists. Official Methods of Analysis. 15. ed. Washington D.C., 2005. p. 71-79.

Ayoola, P. B.; Adeyeye, A. Phyochemical and nutrient evaluation of Carica papaya (pawpaw) leaves. International Journal of Research and Reviews in Applied Science, v. 5, no. 3, p. 325-328, 2010.

Baba, K. M.; Adeleke, M. T. Profitability of snail production in Osun State, Nigeria. Journal of Agriculture and Food Science, v. $4, \quad$ no. $2, \quad$ p. 147-155, 2006. https://doi.org/10.4314/jafs.v4i2.41602

CDC-Centers for Disease Control and Prevention Parasites. Angiostrongyliasis (also known as Angiostrongylus Infection). $2018 . \quad$ Available from: <https://www.cdcgov/parasites/angiostron gylus/epi.html>. Accessed on: Jan. 18, 2019.

Cobbinah, J. R., Vink, A.; Onwuka, B. Snail farming, processing and marketing. Wayeningen: Agromisa Foundation, 2008.

Ejidike, B. N.; Omisade, I. A. Evaluation of dry season rearing of African giant snail (Archachatina marginata) on different food type and apartments. Journal of Fisheries and Aquatic Sciences, v. 2, no. 5, p. 361-365, 2007.

Essien, A. I.; Ebana, R. U. B.; Udoh, H. B. Chemical evaluation of pod and pulp of the fluted pumpkin fruit. Food Chemistry, v. 45, no. 3, p. 175-178, 1992.

FAO - Food and Agriculture Organisation. Farming snails: Learning about snails, building a pen, food and shelter plants. Rome: FAO, 1986. (FAO Better Farming Series, 33). 
Houndonougbo, M. F.; Chrysostome, C. A. A. M.; Odoulami, R. C.; Codjia, J. T. C. Snail shell as an efficient mineral feedstuff for layer hens: Effects and optimum rate. Livestock Research for Rural Development, v. 24, no. 9, p. 1-7, 2012.

Kehinde, A. S.; Adebayo, O.; Usman, J. M.; Meduna, A. J. Effect of the incorporation of Carica papaya leaf and fruit in the ration of Archachatina marginata on the growth performance characteristics. NSAP Proceeding, p. 319-320, 2002.

Lunn, J.; Buttriss, J. L. Carbohydrates and dietary fibres. Nutrition Bulletin, v. 32, no. 1, p.21-64, 2007. https://doi.org/ 10.1111/j.1467-3010.2007.00616.x

Maisarah, A. M.; Asmah, R.; Fauziah, 0. Proximate analysis, antioxidant and antiproliferative activities of different parts of Carica papaya. Journal of Nutrition \& Food Science, v. 4, no. 2, p. 267, 2014. https://doi.org/10.4172/2155-9600.100 0267

Marquardt, W. C.; Demaree, R. S.; Grieve, R. B. Parasitology and vector biology. 2. ed. San Diego, California: Academia Press, 2000.

Mead, A. R. Economic malacology: With particular reference to Achatina fulica. In: Fretter, V.; Peake, J. (Eds.). Pulmonates. London: Academic Press, 1979. v. 2B. p. 150.

Mogbo, T. C.; Nwankwo, O. D.; Nwuzor, I. L. Growth performance of snails (Achatina fulica) fed with three different leaf materials. American Journal of Biology and Life Sciences, v. 2, no. 4, p. 96-99, 2014.

Okafor, F. O. The geographical location of Ogidi: An annual report of Idemili North Local Government Urban Development Bulletin, 2011.

Okonta, B. C.; Agbogidi, O. M. Growth response of Achatina achatina and Archachatina marginata as influenced by three vegetable feeds. ARPN Journal of
Agriculture and Biological Science, v. 6, no. 9, p. 72-75, 2011.

Olufokunbi, B.; Philips, E. O.; Omidiji, J. O.; Ogbonna, U. O.; Makinde, H. T; Apansile, O. J. The economics of commercial domestication of the African giant land snail Archachatina (Calachatina) marginata (Swainson) in Nigeria. In: Henderson, I. F. (Ed.). Slugs and snails in world agriculture. Thornton Heath: British Crop Protection Council, 1989. No. 41. p. 41-48.

Omole, A. J.; Kehinde, A. S. Backyard snail farming at a glance: Back to agricultural sciences (1). Ibadan: Technovisor Agricultural Publication, 2005.

Orisawuyi, Y. A. Practical guides to snail rearing. Lagos: Gratitude Enterprises, 1989.

Opega, J. L.; Orishagbebmi, C. O.; Yusufu, P. A.; Ishaka, N. A. Proximate composition, mineral and phytochemical contents of some leafy vegetables native to Igala kingdom, Kogi State, Nigeria. International Journal of Biochemistry Research \& Review, v. 15, no. 4, p. 1-11, 2016.

Raut, S. K.; Barker, G. M. Achatina fulica Bowdich and other Achatinidae as pests in tropical agriculture. In: Barker, G. M. (Ed.). Molluscs as crop pests. Hamilton, New Zealand: CABI Publishing, 2002. p. 55-114.

SAS - Statistical Analysis System. User's guide, version 8.2. Cary, NC, USA: SAS Institute Inc., 2001.

Sizer, F.; Whitney, E. Nutrition concepts and controversy. 9. ed. Belmont, USA: Thomson Wadsworth Publisher, 2003. 